\title{
The Will of the People: A Critique of (Simple or Weighted) Majority Voting
}

\author{
Peter Emerson \\ The de Borda Institute, Belfast, Northern Ireland \\ Email: pemerson@deborda.org
}

How to cite this paper: Emerson, $P$ (2017). The Will of the People: A Critique of (Simple or Weighted) Majority Voting. Open Journal of Political Science, 7, 311325.

https://doi.org/10.4236/ojps.2017.72025

Received: March 6, 2017

Accepted: April 25, 2017

Published: April 28, 2017

Copyright $\odot 2017$ by author and Scientific Research Publishing Inc. This work is licensed under the Creative Commons Attribution International License (CC BY 4.0).

http://creativecommons.org/licenses/by/4.0/ (c) (i) Open Access

\begin{abstract}
Majority voting is the most ancient, primitive, divisive and inaccurate measure of collective opinion ever invented. Yet many people believe it to be the very foundation of democracy. The consequences are widespread. Firstly, the outcomes of binary referendums are often held to be "the will of the people". Secondly, in the wake of general elections, the new intake of elected representatives then forms a majority administration, with some of them having all the power while others have none. And thirdly, in numerous plural societies, ethnoreligious minorities/majorities feel justified in resorting to violence against that which they perceive to be majority/minority oppression. Accordingly, this article first compares binary voting with other decision-making voting procedures before then discussing what could be the methodology, the implications and the potential consequences of a more accurate non-majoritarian procedure.
\end{abstract}

\section{Keywords}

Consensus Voting, Modified Borda Count, Power-Sharing

\section{Introduction}

Majority voting is not archetypal, and initially, many societies relied on a purely verbal process. In sub-Saharan Africa, for example, "Majority rule was a foreign notion," (Mandela, 1994: p. 25); indeed, in the old days, according to President Julius Nyerere of Tanzania, "The elders... talk until they agree" (Sigmund, 1966: p. 197).

Today, however, binary voting is ubiquitous, in law, business, civic society and not only in politics. It was first used over 2000 years ago by rich male citizens in public forums in Greece, and by rich male ministers in the Imperial Court of the Former Han Dynasty in China (Wang, 1968: p. 176). But there was "nothing re- 
sembling a 'party system' in sixth/fifth century Athens or any other Greek state," (Ste Croix, 2005: p. 198), so people could vote with each other on one day and against on another, without falling into permanently entrenched opposing factions or political parties.

The latter first appeared in England, largely as a result of using binary voting in the House of Commons where the two sides still face each other in a verbal form of what is otherwise gladiatorial combat. Meanwhile in academia, arguments were proffered as to why majority voting was not only practical but also proper. Granted on contentious issues, unanimity was probably impossible, so instead, society was told by Jeremy Bentham and others that they should accept those policies which gave "the greatest good to the greatest number."

Unfortunately, the superlative "greatest" was then corrupted to the comparative "greater", and thus emerged the political structure known as majoritarianism: majority rule by majority vote. Hence, today, the rather extraordinary situation is that so many countries have very different electoral systems but just the one basic decision-making system, the dichotomous (simple or weighted) majority vote.

Accordingly, this article first examines binary voting, with just a few examples as to its usage, not least that of the Brexit vote in the UK. It next considers some other, non-binary decision-making methodologies. In concluding from this analysis that a points system is the more suitable voting mechanism, the text then gives further proof as to the accuracy of preferential voting. And finally, it considers the possible consequences if this more sophisticated voting procedure was to be advocated in the likes of the UN Human Rights Charter.

\section{Binary Voting}

Paradoxical though it may sound, a majority opinion cannot be identified by a majority vote, not least because that opinion has to be identified earlier if it is to be already on the ballot paper. Indeed, in many instances, both in national referendums and in parliamentary votes, the ballot tends to identify, not so much the will of the given electorate, but more the will of the tiny elite who choose the question. Little wonder then that majority voting has been used by umpteen dictators, the first of whom was Napoleon Bonaparte in the year 1800 (Emerson, 2012: p. 143-150). "Shall I be Emperor," he asked in 1804, "yes or no?" and 99 per cent said "yes". "Shall I be Führer?" asked Adolf Hitler in 1936, "yes or no?" whereupon only 98 per cent said "yes".

But binary voting has also been used by an even more numerous number of democrats, a recent example being David Cameron in the UK with his Brexit ballot. "Do you want to be in the European Union?" was his question, but unusually, he lost 48 to 52 per cent. Losing can happen even with a dictator, and the same fate befell the Chilean ruler, Augusto Pinochet, who lost his third referendum in 1988. To pretend, however, that only Napoleon could be the Emperor, only Hitler the Führer, or that the UK could be only in the EU, was a nonsense. So the outcome was also a nonsense; it almost certainly was not the 
will of the people.

This is because a majority opinion cannot be identified if the question is of a 'yes-or-no', positive or negative variety. If everyone is positive about what they want, then it should indeed be possible to identify that which is more or most popular. If, however, some of those voting state only that which is not their will i.e., if they vote "no" or, in the case of Brexit, "leave" - then it will not be possible to identify the collective will. In 2002 in Gibraltar, 99 per cent of the turnout voted against the motion, a proposal for joint sovereignty with Spain, so the vote itself did not identify "the will of the people" but only that which they did not want.

Even with binary voting, there are many variations on the theme: in simple majority voting, success depends upon a minimum of 50 per cent of the turnout; in weighted majority voting, a threshold of two/thirds may be set; in Danish referendums, a minimum turnout of 40 per cent is required, while in Switzerland, success may depend not only upon a majority of the voters but also on a majority of the cantons; in the European Parliament, a formula called qualified majority voting ensures a small country like Malta has rather less influence than the much bigger Germany; in divided societies like Belgium and Northern Ireland, majority support from both groups in society may be required; while in the UN Security Council, certain countries like China have a veto. But, "however democratic simple majority decision initially appears to be, it cannot in fact be so" (Riker, 1982: p. 65).

Politicians like to control agendas, so many countries still use the least sophisticated, the most adversarial, and as noted, the most inaccurate measure of collective opinion-the two-option majority vote, either "option $X$ or option $Y$ ?" or, even worse, “option $\boldsymbol{X}$, yes or no?"

In any plural society, in most debates on contentious problems, there will invariably be a number of proposed solutions "on the table", and on serious topics, it is almost impossible to reduce the complexities of debate into a ballot of only two options. One notable exception was the debate in Sweden in 1955, when a referendum was held on the question, "Which side of the road shall we drive on?" Interestingly enough, however, the ballot paper contained not just two but three options: "left", "right" and "blank". So those who wanted to stay on the "left", and those who preferred to drive on the "right", and even those who on this particular topic were indifferent but who nevertheless were totally committed to the decision-making process, could all participate. And sure enough, over 40,000 voters opted to, as it were, go with the flow: they voted "blank"1.

Logically, that is what should happen: a debate to identify the options, and then a ballot on a (short) list, such that every voter may be positive, and some countries have used multi-option ballots. One of the most interesting was that which took place in New Zealand in 1992 when they debated their electoral system. Several people wanted first-past-the-post, FPTP, the British system. Others

"Interestingly enough, while the people voted overwhelmingly for "left", the government, albeit after a suitable pause, chose "right". 
favoured a form of proportional representation, $\mathrm{PR}$, either the single-transferable vote, STV, as used in Ireland, or the half-FPTP and half-PR system used in Germany. So an independent commission was established and, after due consideration of all proposals, it drew up a short list of five options. As a result, when the ballot took place, (nearly) every voter was able to be positive... and New Zealand now has a compromise: the German system.

\subsection{Brexit Wrecks It}

In many complex disputes, reducing the number of options under debate to a choice of only two on the ballot paper, turns what was a discussion into an argument. Furthermore, the reduction is often a distortion. To take the UK's June 2016 Brexit referendum as an example, the debate (should have) related to at least four options: $A, B, C$ and $D$, the $\mathrm{UK}$ in the:

$A$ European Union, EU,

$B$ European Economic Area, EEA,

$C$ Customs Union, or

$D$ World Trade Organisation, WTO.

In effect, however, the referendum question was, " $A$, yes or no?" So $B, C$ and $D$ supporters voted "no"... or rather, "leave".

The result was: $48 \%$ want $A$,

x\% want $\boldsymbol{B}$,

y\% want $C$,

z\% want $D$,

and $\mathrm{x}+\mathrm{y}+\mathrm{z}=52 \%$.

If instead of " $A$, yes or no?" the question had been " $B$, or $C$, or $D$, yes or no?" doubtless in all three, a majority would again have said "no". In other words, that positive-or-negative vote did not, and could not identify the will of the people. In a four-option debate, any two-option question is at least inappropriate and often just silly. Hence the current debate in the UK: nobody knows for sure what it is the word Brexit actually means, that is, we still don't know the will of the people. Furthermore, as happens in so many societies, the debate is yet again reduced to just two options: is the future to be a "soft" or a "hard" Brexit ${ }^{2}$.

\subsection{Italian Spaghetti}

In November 2016, the Italian government of Matteo Renzi made a similar mistake. The debate concerned the constitution and there are, of course, numerous ways to formulate such a document. He however chose what he wanted, and he then decided that he wanted the Italian people to want it too, so all the complexities of debate were reduced to just two options: one new proposal or the status quo. Furthermore, he stated that he would resign if the referendum was then rejected, so distorting the distortion even further. Sure enough, he lost. And

${ }^{2}$ These two adjectives, "soft" and "hard" were used in London in 1903, to describe the two wings of the All-Russian Congress of Social Democrats. They voted, using a majority vote, and they then split into the Bolsheviks (members of the majority, bolshinstvo) and Mensheviks (minority, menshinstvo). In fact, however, because of those who abstained, neither side had a majority. 
nobody knows, in regard to the constitution, what actually is the will of the people.

\subsection{A French Conundrum}

The same was true in France in 2005 when the debate was on the subject of a new treaty for the EU. The question was, "Do you approve... yes or no?" So those who did approve voted "yes". And those who did not voted "no". But those who did not like the EU at all also voted "no". And those who did not like Jacques Chirac, the then President, also voted "no". And those who did not like MacDonalds, or the prospects of Turkish accession to the $\mathrm{EU}$, or je ne sais quoi, also voted "no". So "no" won. And yet again, nobody knew what was, in fact, the will of the people.

\subsection{Conflict Zones}

In the early 1990s, Yugoslavia was beginning to fall apart. Accordingly, the EU set up the so-called Badinter Commission, a team of five Supreme Court judges, and they recommended that any region wishing to exercise self-determination should hold a referendum... by implication, a binary poll. As a result, there were plebiscites on independence all over the place. Some were recognised, others not, but as Sarajevo's legendary newspaper Oslobodjenje observed on 7.2. 1999, "all the wars in the former Yugoslavia started with a referendum".

The world learnt nothing from this horrible history, the West continued to advocate binary ballots on self-determination, as for example in South Sudan; the latter has since imploded. Furthermore, the above quotation could now just as easily apply to Ukraine; first came the referendum in Crimea, then two others in Eastern Ukraine... and then war. Yet still there are those who talk of binary referendums as if they are nice and democratic, as if these binary questions can indeed identify the will of the people... in places like, for example, Scotland, Kashmir and Taiwan.

\section{Non-Binary Voting Procedures}

If there are only two options on the ballot paper, there is only one way of voting, namely majority voting. In today's world, however, as demonstrated in Sweden, there should be all too few instances when only two options represent the entire debate.

All other forms of voting are multi-optional; some like plurality voting still offer the voter only one preference; others like approval voting let the voter choose more than one option; and a third category allow the voters to cast preferences. To compare the accuracy of these various methodologies, consider Table 1, a voters' profile in which 15 persons (of alternate gender) express their preferences on some or all of five options, E, F, G, H and I.

At first glance, it would seem that option $E$ is very divisive, and option $I$ is its opposite. The other three options all seem better suited to represent the consensus of the 15 , but let us now examine the various voting mechanisms, to see 
Table 1. A voters' profile.

\begin{tabular}{|c|c|c|c|c|c|c|c|c|c|c|c|c|c|c|c|}
\hline \multirow{2}{*}{ Preferences } & \multicolumn{15}{|c|}{ Voters } \\
\hline & $i$ & $j$ & $k$ & 1 & $m$ & $n$ & $p$ & $q$ & $r$ & $s$ & $t$ & $u$ & V & $w$ & $x$ \\
\hline $1^{\text {st }}$ & $E$ & $E$ & $E$ & $E$ & $E$ & $F$ & $F$ & $F$ & $G$ & $H$ & $H$ & $I$ & $I$ & $I$ & $I$ \\
\hline $2^{\text {nd }}$ & $F$ & $G$ & $H$ & $G$ & $G$ & $G$ & $G$ & $G$ & $F$ & $G$ & $G$ & $G$ & $G$ & $G$ & $H$ \\
\hline $3^{\text {rd }}$ & $G$ & $H$ & $F$ & $H$ & $H$ & $H$ & $H$ & $H$ & $H$ & $F$ & $F$ & $H$ & $H$ & $H$ & $G$ \\
\hline $4^{\text {th }}$ & $H$ & $I$ & $I$ & $F$ & - & - & - & $I$ & $I$ & $I$ & $I$ & $F$ & $F$ & $F$ & $F$ \\
\hline $5^{\text {th }}$ & $I$ & - & - & - & - & - & - & - & - & $E$ & $E$ & $E$ & $E$ & $E$ & $E$ \\
\hline
\end{tabular}

which is or are the more accurate.

\subsection{Plurality Voting}

This methodology considers only the $1^{\text {st }}$ preferences cast, so the result is $E 5, I 4$, $F 3, H 2$ and $G 1$. Option $E$, then, is deemed to be the winner, and it is all very democratic. After all, option $E$ is the $1^{\text {st }}$ preference of five voters, but the fact that it is the $5^{\text {th }}$ preference of six voters is just ignored. This methodology, then, is hopelessly unsuited to any decision-making process in which there are more than two options on the table, or any election in which there are more than two candidates. Sadly, however, under the name of FPTP, it is used as an electoral system in the USA, the UK and many former British colonies.

\subsection{The Two-Round System, TRS}

If no one option gains a majority in the first round plurality vote, a second round majority vote can be taken between the two leading options from the first round. In the above example, the first round result of $E 5, I 4, F 3, H 2$ and $G 1$ leads to a second round between options $E$ and $I$, and, if the voters' preferences stay the same, the result is now $E 5 I$, so $I$ is now the winner, and it is all very democratic. This TRS is used as an electoral system in France and in some former French colonies. Because it relies on the unreliable plurality vote in the first round, however, this system too can be very capricious.

\subsection{The Alternative Vote, $\mathrm{AV}^{3}$}

This procedure is like a series of plurality votes, the least popular option being eliminated after each stage, and its votes transferred in accordance with the respective voters' $2^{\text {nd }}$ and/or subsequent preferences.

So, after a first round result of $E 5, I 4, F 3, H 2$ and $G 1$, option $G$ is eliminated and its vote (from Table 1 ) goes to $F$. The score is now $E$ 5, $I 4, F 4$ and $H$ 2. Option $H$ is now the smallest so it too is eliminated, and its two votes go (not to $G$ which is now out of the running, but) to $F$ again, leading to a score of $E 5, I$ 4 and $F$. And that is the end of $I$, and all four of $I$ s voters then transfer their support to option $F$, so the final result is $E 5 F 10$, so $F$ is now the most popu-

${ }^{3} \mathrm{AV}$ is also known as instant run-off voting, IRV, in North America; as the single transferable vote, $\mathrm{STV}$, in the UK, and as preferential voting, PV, in Australasia. 
lar... and it is still all very democratic.

$\mathrm{AV}$ is used in Australian elections and in Chinese village councils.

\subsection{Approval Voting}

There are no preferences in approval voting; instead, every "tick" for an option is regarded as an "approval", leading to scores of $E 11, F 13, G 14, H 15$ and $I 11$. So the winner is now option $H$... and it is again all very democratic.

Approval voting actually encourages the intransigent to support only his favourite option, while the consensual voter may "approve" of more than one option; but in so doing, she reduces the chances of her favourite. Other methodologies like range voting can entice voters to even more intransigent behaviour, as they give voters a fixed number of points to award, either to lots of options or maybe to just a few or even only one of them. Approval voting is not used in any national elections.

\subsection{The Modified Borda Count, MBC}

The $\mathrm{MBC}$ is a points system. Unlike any of the above, it takes into consideration all of the preferences cast by all the voters. So it is definitely very democratic and likely to be more accurate. In a ballot on $n$ options, a voter may cast $m$ preferences where $n \geq m \geq 1$, and points are awarded to:

$\left(1^{\text {st }}, 2^{\text {nd }} \cdots\right.$ last preferences)

cast, according to the rule

$(m, m-1 \cdots 1)$.

In the current example, Ms $I$ casts just 4 preferences, giving 4 points to option $E$, 3 to $G, 2$ to $H$ and 1 to $F$. Mr $p$ in contrast gives just 3 points to option $F, 2$ to $G$ and 1 to $H$. The scores are then $G 45, H 39, F 34, I 29$ and $E 26$. Elections under not an $\mathrm{MBC}$ but just a $\mathrm{BC}$ are used in Slovenia and, with a rather different counting formula, in Nauru.

A comparison of all five voting procedures is summarised in Table 2.

In other words, the democratic result could be $E$ or $F$ or $G$ or $H$ or $I$; it could be anything at all. Furthermore, the social ranking with the MBC - G H F I E is the exact opposite of that which is the outcome of the plurality vote - $E I F H$ $G$. So something is wrong.

In a nutshell, some of the above methodologies are inaccurate; a few may be a bit better; but "It seems clear that Borda's criterion is the soundest method of

Table 2. Democratic Decision-Making.

\begin{tabular}{ccccccc}
\hline Methodology & Social Choice & \multicolumn{5}{c}{ Social Ranking } \\
\hline Plurality Voting & $E$ & $E 5$ & $I 4$ & $F 3$ & $H 2$ & $G 1$ \\
TRS & $I$ & $I 8$ & $E 5$ & - & - & - \\
AV & $F$ & $F 10$ & $E 5$ & - & - & - \\
Approval voting & $H$ & $H 15$ & $G 14$ & $F 13$ & $E / I 11$ \\
MBC & $G$ & $G 45$ & $H 39$ & $F 34$ & $I 29$ & $E 26$ \\
\hline
\end{tabular}


identifying the [option which] is most generally popular... or at least the most acceptable" (Dummett, 1997: p. 71). Indeed, "only the Borda Count offers an accurate accounting of the voters' preferences" (Saari, 2001: p. 187). Results of any FPTP elections may well be fake popularities, and one obvious example is Donald Trump.

\section{Further Proof on the Accuracy of Consensus Voting}

In an $\mathrm{MBC}$, he who casts just one preference (and says nothing about the other options) gives 1 point to that option (and zero to the others). She who casts two preferences gives 2 points to her favourite (and 1 point to her $2^{\text {nd }}$ choice). And so on. Thus he who in a five-option ballot casts all five preferences gives his favourite 5 points, (his $2^{\text {nd }}$ choice 4 , his $3^{\text {rd }} 3$, etc.). Furthermore, in the campaign before the vote, the protagonist would be well advised to ask her supporters to cast full or nearly full ballots, and an $\mathrm{MBC}$ can be the catalyst of a much more tolerant politics.

So the mathematics of the count encourages both the voters to cast lots of preferences, and therefore the protagonists to ask them to do so. Accordingly, during the course of the debate which precedes the vote, the politicians shall be obliged to declare their preferences, and this often happens in Irish PR-STV elections. One obvious consequence is that the debates themselves become much more nuanced, and discussions do not so readily descend into arguments.

There is, furthermore, a mathematical consequence. Consider a debate in which persons are discussing five possible tax rates, $A 40 \%, B 45 \%, C 50 \%, D$ $55 \%$ and $E 60 \%$. If $\mathrm{Mr} i$, say, has a $1^{\text {st }}$ preference of $E$, his $2^{\text {nd }}$ preference will probably be $\boldsymbol{D}$, his $3^{\text {rd }} \boldsymbol{C}$ and so on, $\boldsymbol{B}$ and $\boldsymbol{A}$. If another voter has a $1^{\text {st }}$ preference of $B, M s j$, her $2^{\text {nd }}$ preference might be $A$, with subsequent $3^{\text {rd }}, 4^{\text {th }}$ and $5^{\text {th }}$ preferences of $C, D$ and $E$; or maybe, as is the case with $\mathrm{Mr} \mathrm{k}$, a $1^{\text {st }}$ preference of $\boldsymbol{B}$ but a $2^{\text {nd }}$ and $3^{\text {rd }}$ of $C$ and $D$, a $4^{\text {th }}$ of $\boldsymbol{A}$ and a $5^{\text {th }}$ of $\boldsymbol{E}$ (Figure 1 ).

If however, as shown in Figure 2, if another voter like $\mathrm{Mr} m$ has preferences of $1^{\text {st }} D, 2^{\text {nd }} B, 3^{\text {rd }} E, 4^{\text {th }} \boldsymbol{A}$ and $5^{\text {th }} \boldsymbol{C}$, then his set of preferences will show two peaks... and little rhyme or reason.

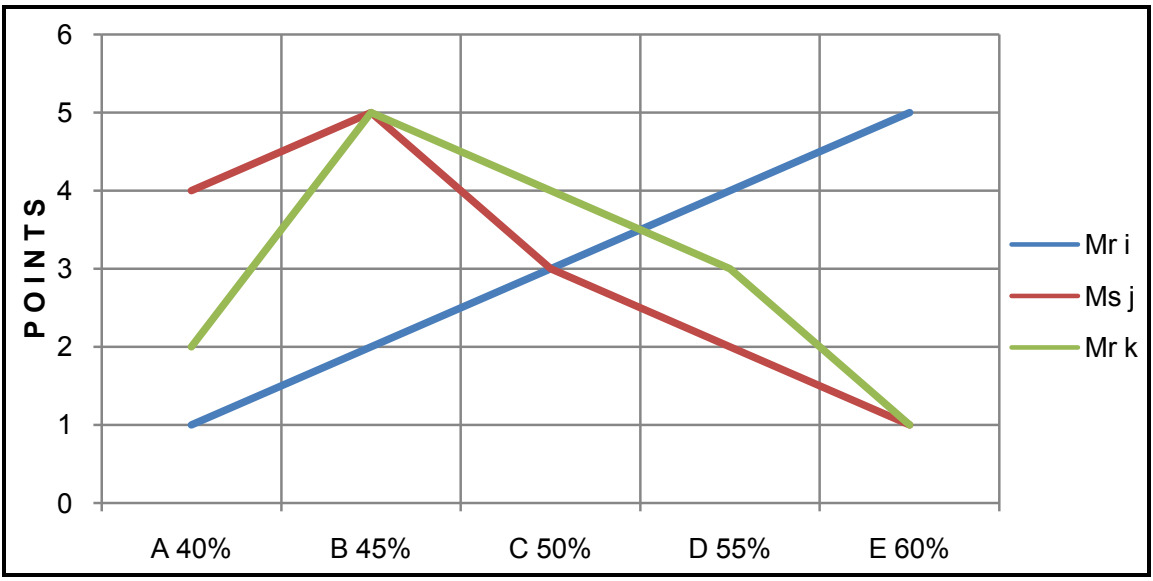

Figure 1. Single-peaked preferences. 
So, returning to Figure 1, in those debates where it is possible to regard the options as being on a spectrum of cheap to expensive, "soft" to "hard", or whatever, those who vote positively will invariably have single-peaked sets of preferences. In which case, the collective option, the voice of the people, will also be single peaked, and this is shown in Figure 3.

$\operatorname{Mr} i(1,2,3,4,5)+\operatorname{Ms~j}(4,5,3,2,1)+\operatorname{Mrk}(2,5,4,3,1)=\operatorname{Total}(7,12,10,9$, 7).

Sometimes, as in the collective will shown in Figure 3, the resulting set will show a very clear peak, and the steeper this summit, the greater the degree of consensus. Or maybe there is rather less consensus, and opinions are spread on a plateau.

For example, the collective will of three quite different voters' profiles might appear like the orange line in Figure 4, consensus $i$, in which case there is a considerable degree of consensus for option $\boldsymbol{B}$. With the green line, consensus ii, it is still true to say that a consensus has been identified, and its exact location is at the peak of the "curve" between $C$ and $D$, somewhere near 53\% (but see para 4.2

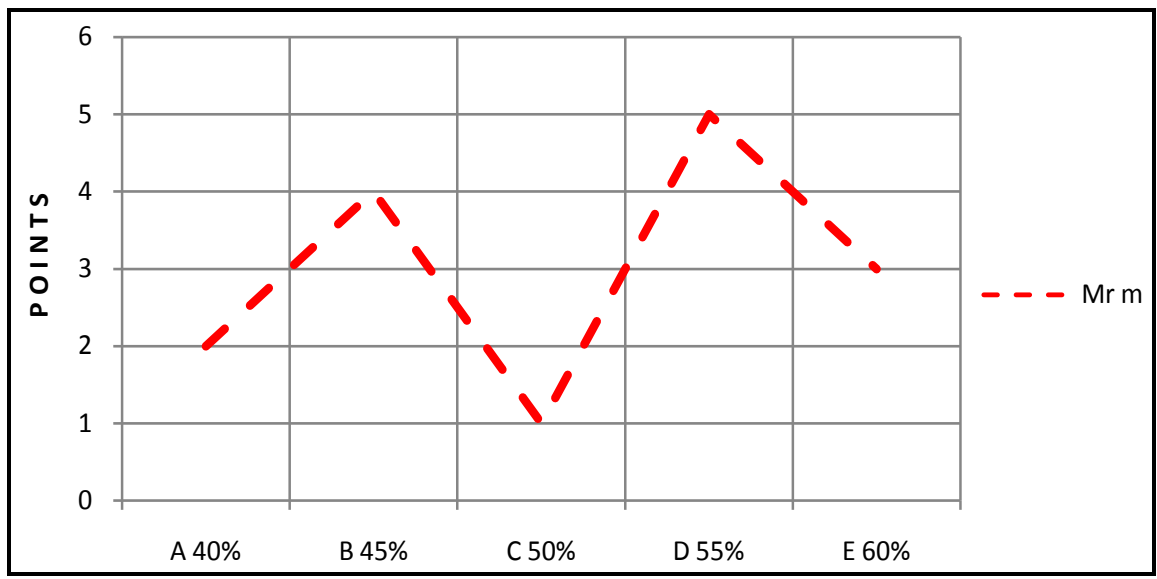

Figure 2. A twin-peaked set of preferences.

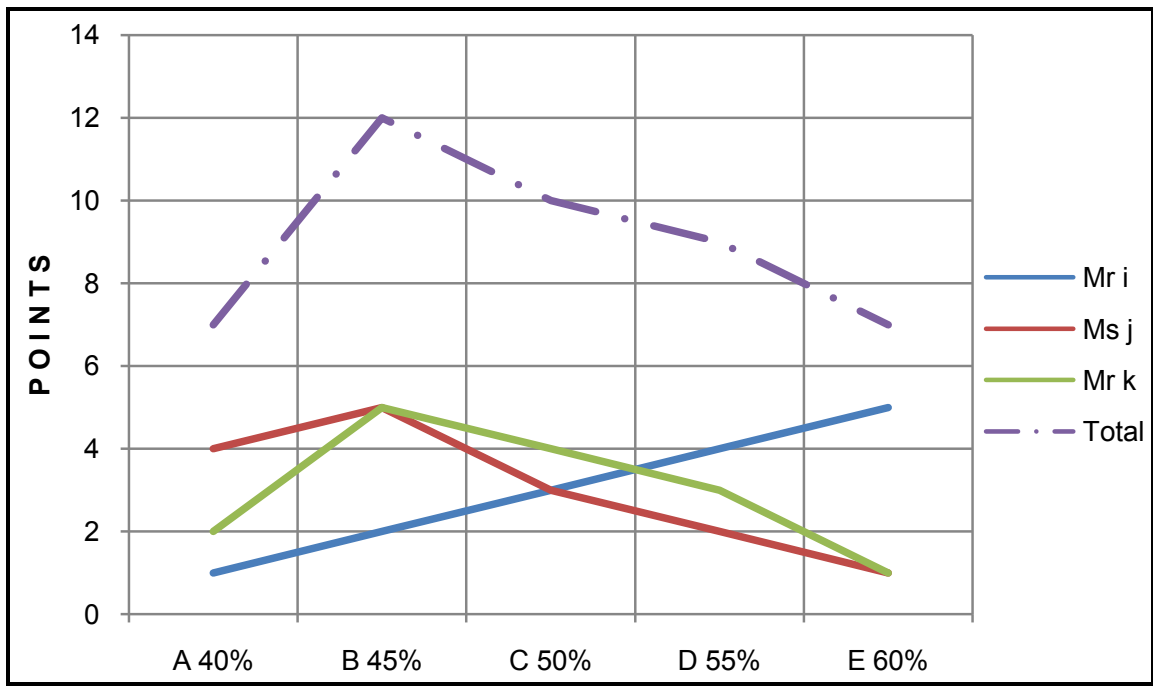

Figure 3. The collective will. 


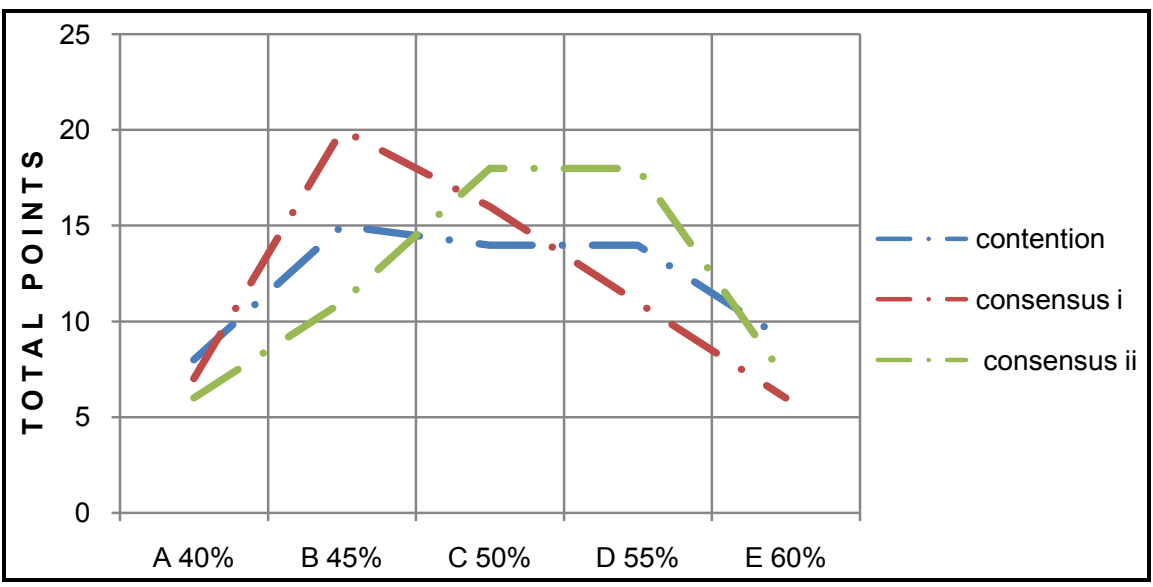

Figure 4. The consensus.

for a more exact assessment). With the blue line, in contrast, there is a degree of contention; it is nevertheless fair to say that the outcome is again at the peak, at about $48 \%$.

\subsection{A Consensus Debate}

As noted earlier, a major criticism of majority voting is that it allows those in power to choose the question and, in many instances, their question is the answer. Accordingly, in any consensus debate, the choice of options must be decided independently - as was the case in New Zealand's referendum of 1992, (para 2). In a parliamentary setting, this act of arbitration should be the responsibility of the Speaker; in public enquiries, the commissioners can do this; while in business, civic society and in village councils, this task may be given to one or more facilitators, normally about three of them.

When the debate is initiated, those concerned - members of a parliament or of the public, as appropriate-may offer their proposals, and as long as the latter are relevant to the debate and conform to some agreed standard like the UN Charter on Human Rights, all shall be accepted. In debate, these suggestions may be questioned, opinions may be clarified, options may be amended, and so on. Throughout these proceedings, the consensors-a generic term to describe those policing the debate-shall maintain a list of options currently 'on the table' and computer screen, if not also on a dedicated website. The list shall be balanced and fair, so, if need be, options may be edited and/or composited and/or, if agreed to unanimously, even eliminated.

If at the end of the debate, the list of options has been reduced to one, this last may be regarded as the verbal consensus of all concerned... as was the case, more or less, in African democracy, (para 1). If however, a verbal consensus has not emerged-on most topics in many parliaments, this is the more likely scenarioand if a number of options still remain in contention, the chair shall ask the consensors to draw up a ballot of about five options. If those who proposed these policies are satisfied that their particular option is included, either verbatim or amended or in composite, then all concerned may proceed to cast their preferences. 


\subsection{A Precise Consensus}

The total number of points received by any one option, divided by the maximum number of points it could have received, is that option's consensus coefficient. So, in the five option ballot shown in Table 1 with 15 people voting, the maximum score would be fifteen $1^{\text {st }}$ preferences, which is $15 \times 5$ points $=75$ points.

An option's consensus coefficient, therefore, is a measure of, not only that option's support among those voting, but also of the degree to which everyone has participated in the voting process. If those 15 people all give a hypothetical option $X$ their $1^{\text {st }}$ preference, and if all 15 have submitted full ballots of five preferences, then option $X$ does indeed get $15 \times 5=75$ points, the maximum, and a consensus coefficient therefore of 1.0. If however those 15 voters have cast only one preference each, then option $X$ will get only $15 \times 1=15$ points and a consensus coefficient of only 0.2 , which is probably not enough (see below).

The results for Table 1 voters' profile are shown in Table 3.

Prior to any debate, all should be aware of the relevant standing orders, and these should stipulate the minimum consensus coefficient required for a decision to be then regarded as binding. In other words, to identify the will of a particular group of people, it is necessary a) for a certain threshold minimum number of them to participate, and b) for a certain degree of agreement to have been achieved among those participants. A debate in which many voters have submitted only partial ballots and which produces the dotted purple collective will shown in Figure 5, even though it is single-peaked, should not be regarded as conclusive.

For information, the consensus coefficients achieved in the three collective wills shown in Figure 5 are as follows: consensus 1) $=1.0$; consensus 2) $=0.95$; and dissent $=0.4$. The recommended threshold for most parliaments is 0.55 or 0.6 , but in plural societies, this can be adjusted to ensure a minimum degree of support from all the relevant major ethno-religious groups.

\section{The Consequences}

In today's world, as implied earlier, many people "are captivated by what may be called the mystique of the majority," (Dummett, 1997: p. 71). Ballots like the above Brexit referendum are assumed by countless politicians, journalists and academics to represent "the will of the people" and this encourages others like

Table 3. Consensus coefficients.

\begin{tabular}{ccc}
\hline Option & Points & Consensus Coefficient \\
\hline $\boldsymbol{H}$ & 45 & 0.60 \\
$\boldsymbol{F}$ & 39 & 0.52 \\
$\boldsymbol{I}$ & 34 & 0.45 \\
$\boldsymbol{A}$ & 29 & 0.39 \\
\hline
\end{tabular}




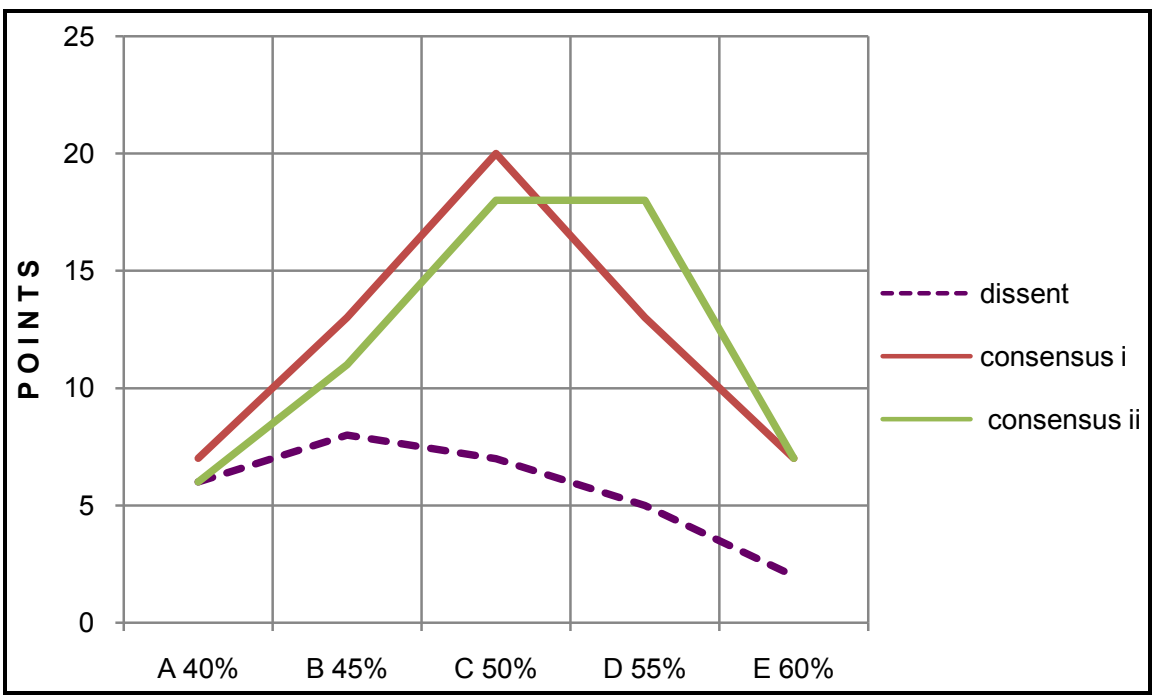

Figure 5. Degrees of consensus.

Marine Le Pen in France and Geert Wilders in the Netherlands to do the same. If the forces of populism continue to dominate, the logic of it all suggests that the people will continue to vote "no" until eventually there is nothing. This is so dangerous.

Meanwhile, as in Italy so too in Turkey, if rulers like Recep Tayyip Erdoğan can decide what they want and then, on the basis of perhaps only a part of society, get exactly what they want, this too is so dangerous.

\subsection{Majority Rule}

For the moment, however, people believe majority voting to be democratic. Furthermore, they believe in majoritarianism-majority rule by majority vote. So, not in law or business or civic society but in politics, once a representative body has been elected, that body shall divide into two, the bigger "half" to form the government, the smaller to form the opposition.

In those parliaments elected by FPTP, there is often a single party which wins (not necessarily the most votes but) the most seats, so it can then claim to represent the majority. Accordingly, it then forms the government. A party which wins by even only the smallest of margins, just 51 per cent or less, nevertheless claims 100 per cent of the power.

Countries which use PR electoral systems are more likely to emerge, in the wake of an election, with no one party having a majority of the seats. In such circumstances, what then happens may often be little short of bizarre, as open and transparent elections involving everybody, are followed by closed and opaque discussions involving only the politicians, as often as not behind closed doors.

The process can be problematic and protracted, the results often even more bizarre (Emerson, 2016: p. 31-64). Sometimes, as can happen in Germany, the two big parties form what is called a grand coalition, but this means the spoils of office have to be shared. What often happens, therefore, is that a big party will 
seek to co-operate with one or more of the smaller factions, so to retain more influence, but hence the extraordinary administration in India in 1998 when a coalition of 41 parties was in power. On other occasions, as has occurred in Austria, the biggest party is forced into opposition by a combination of other less popular parties.

A further consequence can be dangerous: in divided societies as in Israel, the chances of a minority, the Arab List, ever getting into government are probably about zero; furthermore, the current administration has a majority of only one, and this means the extremist tail can sometimes wag the dog. The same is the case for the Kurdish party in Turkey.

Needless to say, however, all of these forms of administration are regarded as democratic, as too is the all-party structure used by the Swiss. The latter have devised a ratio by which the five biggest parties in parliament all share the seven-person Federal Council, a form of joint presidency. The only other jurisdictions to have an all-party structure are former conflict zones, but most of the formulas by which ministerial posts are shared are partisan if not indeed openly sectarian, as for example in the Taif Accord in Lebanon or in the Belfast Agreement in Northern Ireland.

When almost anything is possible, it is hardly surprising that the politicians' negotiations can often be protracted. The most recent example was in Spain, where it took two elections and, in total, 313 days to form a government. And all of this nonsense is because people believe in majoritarianism-majority rule by majority vote.

\subsection{A More Consensual Polity}

If it were to be decided that majority voting is indeed inaccurate, if all were to agree that the democratic norm should be a form of preferential decision-making such as the MBC, then, because the latter is non-majoritarian, there would be no further justification for majority rule. Instead, the democratic process would involve, firstly, the election of a parliament, and then, the election by that parliament of a government, an all-inclusive coalition.

It is further submitted that if so-called stable democracies practiced such a form of power-sharing, it would be easier to persuade those involved in conflicts that all of them should also share power with all of their fellow citizens.

Secondly, no one person - like Trump - should ever be in the position of having 100 per cent of the power. He does not represent everybody. Indeed, he cannot do so. It cannot be right, therefore, that he and his chosen acolytes can decide all matters of policy (subject only to a few checks and balances).

\section{Conclusion}

The world is now at a most dangerous stage, as the forces of populism and xenophobic nationalism appear to dominate more and more on the international stage. Majoritarianism has been the cause of so much suffering in the world, in conflicts from Rwanda to Ukraine. Similarly in China, many conflicts of the last 
century were based on the ubiquitous human tendency of viewing topics dichotomously, firstly during the civil war against the Kuomintang and later in the campaign against the rightists.

Today, however, the problem is truly global. If the western world continues to use majority voting; to believe in the "alternative facts" presented in the outcomes of such ballots; to hold majoritarian referendums in the country at large or binary votes in parliaments and international forums, there is the danger that the likes of Trump may dominate in many places, thereby increasing the possibilities of conflict both within and between nations. The need for a more inclusive, consensual and accurate polity could hardly be more urgent.

\section{References}

Dummett, M. (1997). Principles of Electoral Reform. Oxford: Oxford University Press.

Emerson, P. (2012). Defining Democracy. Heidelberg, New York, London: Springer.

Emerson, P. (2016). From Majority Rule to Inclusive Politics. Heidelberg, New York, London: Springer.

Mandela, N. (1994). Long March to Freedom. London: Little Brown and Company.

Riker, W. H. (1982). Liberalism against Populism. Illinois: Waveland Press.

Saari, D. (2001). Decision and Elections. Cambridge: Cambridge University Press. https://doi.org/10.1017/CBO9780511606076

Sigmund, P. E. (1966). The Ideologies of Developing Nations. New York: Frederick A Praeger.

Ste Croix, G. E. M. (2005). Athenian Democratic Origins. Oxford: Oxford University Press.

Wang, Y.-C. (1968). An Outline of the Central Government of the Former Han Dynasty. In J. L. Bishop (Ed.), Studies of Governmental Institutions in Chinese History. Harvard-Yenching Institute Studies XXIII. 


\section{Abbreviations}

$\mathrm{AV}=\mathrm{IRV}=\mathrm{PV}=\mathrm{STV}:$ alternative vote

BC: Borda count

EEA: European Economic Area

EU: European Union

FPTP: first-past-the-post

$\mathrm{IRV}=\mathrm{AV}=\mathrm{PV}=\mathrm{STV}$ : instant run-off voting

MBC: modified Borda count

PR: proportional representation

$\mathrm{PV}=\mathrm{AV}=\mathrm{IRV}=\mathrm{STV}$ : preference voting

$\mathrm{STV}=\mathrm{AV}=\mathrm{IRV}=\mathrm{PV}$ : single transferable vote

UK: United Kingdom

UN: United Nations

USA: United States of America

WTO: World Trade Organisation

Submit or recommend next manuscript to SCIRP and we will provide best service for you:

Accepting pre-submission inquiries through Email, Facebook, LinkedIn, Twitter, etc. A wide selection of journals (inclusive of 9 subjects, more than 200 journals)

Providing 24-hour high-quality service

User-friendly online submission system

Fair and swift peer-review system

Efficient typesetting and proofreading procedure

Display of the result of downloads and visits, as well as the number of cited articles

Maximum dissemination of your research work

Submit your manuscript at: http://papersubmission.scirp.org/

Or contact ojps@scirp.org 